\title{
THE PROTECTION OF INTERNALY DISPLACED PERSONS BY INTERNATIONAL MIGRATION LAW
}

Eveline Vieira Brigido ${ }^{1}$

Fabiola Wust Zibetti

Recebido em: 13/11/2017 Aceito em: 07/06/2018 Liton Lanes Pilau Sobrinho ${ }^{2}$

evelinebrigido@gmail.com fwzibetti@gmail.com liton@upf.br

\begin{abstract}
This paper aims to analyze how international migration law protects internally displaced persons. First of all, there is a general approach about the history of International Regulations of migrations and about the concept of displaced person. Afterwards, it will be analyzed today's regulation of displaced persons by International Law. At the end, it is concluded that there are a few legal documents that protect these persons, and internationally there are only the Guiding Principles. Although all these principles are foreseen in many human rights treaties, new legal documents should be developed for the adequate protection of internally displaced persons.
\end{abstract}

Keywords: Internally displaced persons. International law. Human rights. International humanitarian law.

\section{INTRODUCTION}

Human migration has been constant in history. People can migrate for various reasons and migration can be voluntary or not. When one decides to flee by self convenience, it is called voluntary migration. There are forced migration, when someone is forced to flee, like during a war or persecution, or in case of violation of human rights. ${ }^{3}$

Nowadays, the international society faces a migration crisis because of many conflicts, which forces people to leave their homes. According to the United Nations Refugee Agency (UNHCR), by the end of 2016, 65,6 million people were forced to flee. About 40 million are internally displaced persons (IDPs), it means that almost $2 / 3$ of persons who leave their homes did not cross the borders of their own country. The highest numbers of internally displaced persons in 2016 are seen in Colombia (7,2 million), Syria (6,3 million), Iraq (3,3 million), Sudan (3,3 million) and Yemen (2,5 million). ${ }^{4}$

Therefore, this paper aims to analyze the legal protection of internally displaced persons under international migration law. This research is very current relevant, once the legal protection of people

\footnotetext{
${ }^{1}$ Escola Superior de Propaganda e Marketing - ESPM Sul - Porto Alegre - Rio Grande do Sul Brasil

2 Universidade de Passo Fundo - UPF - Passo Fundo - Rio Grande do Sul - Brasil

3 JUBILUT, Liliana Lyra; MENICUCCI, Silvia. A necessidade de proteção internacional no âmbito da migração. Revista Direito GV. São Paulo, v. 6, n. 1, p. 275-294, jan-jun 2010. p. 281.

4 UNITED NATIONS. The UN refugee agency. Global trends 2017. Disponível em: $<$ http://www.unhcr.org/dach/wp-content/uploads/sites/27/2017/06/2016 Global Trends WEBembargoed.pdf>. Acesso: 06 jul. 2017.

ORGANIZAÇÃO DAS NAÇÕES UNIDAS. ACNUR: deslocamento forçado atinge recorde global e afeta 65,3 milhões de pessoas. 21 jun 2016. Disponível em: <https://nacoesunidas.org/acnurdeslocamento-forcado-atinge-recorde-global-e-afeta-653-milhoes-de-pessoas $>$. Acesso em: 25 jun 2017.
} 
in a danger situation is one of the most polemic themes. ${ }^{5}$ And this situation may suddenly get worse because soon IDPs may become refugees. Considering the huge number of displaced persons, if they cross the borders of their countries it will aggravate the international humanitarian crisis.

In this way, this paper is divided into three sections. First, it will be studied the history of migrations legal protection under international law. Afterwards, it will be studied the concepts of internally displaced persons according to international and regional legal documents. At the end, these documents will be interpreted to achieve the comprehension of the international law protection of the IDPs and it will be made a comparison between these documents and the most important international treaties of human rights.

This is a qualitative and exploratory research, which was based on primary and secondary sources. As primary sources it was analyzed international treaties and other legal documents, General Assembly of the United Nations resolutions, UNHCR documents and United Nations Human Rights Council (OHCHR). Besides these documents, it was also studied books, articles and research on the United Nations (UN) website, UNHCR website, Organization of American State (OAS) website and African Union Organization website.

\section{THE HISTORY OF LEGAL PROTECTION OF MIGRATION}

Migration is the movement of people who leave their origin town to move to other cities in their own country or even to other countries. There are many reasons for this movement: wars, genocide, crime against humanity and other violations of human rights, economic or even environmental factors. ${ }^{6}$ This paper will study the forced migration caused by conflicts, persecutions and violations of human rights, which does not cross the state borders. Nevertheless, for the study of this kind of migration it is necessary to comprehend the migration that crosses the borders.

The people who leave their country because of persecution are named "asylum seeker", and once they receive the legal protection they become a "refugee".

The first international legal rules about refugee were created by the League of Nations. In fact, there was not an office as the UNHCR. The Covenant of the League of Nations did not mention refugees, but expressed, in article 25, that the League and its member-states would encourage the cooperation with the International Committee of the Red Cross (ICRC). In 1921, the president of the ICRC asked the League of Nations to analyze the refugee issue and, six days ahead, the League adopted its first resolution. In October, Fridtjof Nansen was named High Commissioner for Russians Refugees. ${ }^{7}$

\footnotetext{
${ }^{5}$ OLIVEIRA, Eduardo Cançado. A proteção jurídica internacional dos deslocados internos. Revista do Instituto Brasileiro de Direitos Humanos. v. 5, n. 5, p. 73-92, 2004. p. 73.

6 INTERNATIONAL ORGANIZATION FOR MIGRATION. Key migration terms. Disponível em: $<$ https://www.iom.int/key-migration-terms $>$. Acesso em: 11 jul 2017.

7 ANDRADE, José Fischel de. A política de proteção a refugiados da Organização das Nações Unidas - sua gênese no período pós-Guerra (1946-1952). Brasília: UnB. 2006. Disponível em: < http://repositorio.unb.br/handle/10482/3726>. Acesso em: 01 jun 2017. p. xliv.
} 
The League of Nations has adopted a collective approach about the concept of refugee. The condition to be a refugee was the following: the persons should be outside their country of origin and without the protection of the government of that State. A Russian refugee, for example, was defined as any person of Russian origin who did not enjoy the protection of the Soviet Union and who had not acquired another nationality. ${ }^{8}$

Therefore, the first refugee office was created for the benefit of Russians, once many of them left their home because of the birth of the Union of Soviet Socialist Republics (USSR). And they also lost their nationality. ${ }^{9}$

In 1924, people from other nationalities obtained the same protection, but the League has never defined the term "Refugee". The conditions to enjoy the protection were: absence of protection from the country of origin and having not acquired another nationality. Thus, in the beginning, the concept of refugee was related to the concept of war and all the protection was temporary. ${ }^{10}$

In 1930, it was created the Nansen International Office for Refugees, that drafted the Refugee Convention of 1933. Although limited in its scope, this Convention was the beginning of the International Refugee Law, which is based on the principle of non-refoulement, that is, no refugee or asylum seeker could be sent to any country where his life or freedom is threatened. ${ }^{11}$

In 1938, Norway proposed the uniformization of the treatment for refugees and the creation of a single international office for their protection. Thus, after the end of The Nansen Office, the League has created the League of Nations High Commissioner for Refugees. ${ }^{12}$

At the same token, the United State of America established the Intergovernmental Committee for Refugees, for supplementary tasks regarding the High Commissioner, protecting views from Germany and Austria. "Its functions were limited to negotiate with German authorities to obtain organized emigration, and with authorities from other countries about the possibility to receive these refugees in their territories."13

After the Second World War, the League of Nations finished its works and the United Nations was created. Therefore, the League of Nations High Commissioner also finished its works and the Intergovernmental Committee for Refugees worked until 1947. As the Second War produced a huge number of refugees, the United Nations Economic and Social Council (ECOSOC) and the preparatory commission of the International Organization for Refugees began to manage the international forced migration caused by conflict and persecution. ${ }^{14}$

\footnotetext{
${ }^{8}$ ANDRADE, José Fischel de. A política de proteção a refugiados da Organização das Nações Unidas - sua gênese no período pós-Guerra (1946-1952). Brasília: UnB. 2006. Disponível em: < http://repositorio.unb.br/handle/10482/3726>. Acesso em: 01 jun 2017. p. xliv.

${ }_{9}^{9}$ ANDRADE, José Fischel de. O Brasil e a organização internacional para os refugiados. p. xliv.

10 JUBILUT, Liliana Lyra. $O$ direito internacional dos refugiados e sua aplicação no ordenamento jurídico brasileiro. São Paulo: Método, 2007. p. 74.

${ }_{11}^{11}$ JUBILUT, Liliana Lyra. 0 direito internacional dos refugiados e sua aplicação no ordenamento jurídico brasileiro. p. 75.

${ }_{12}$ JUBILUT, Liliana Lyra. $\mathbf{O}$ direito internacional dos refugiados e sua aplicação no ordenamento jurídico brasileiro. p. 76.

${ }^{13}$ ANDRADE, José Fischel de. O Brasil e a organização internacional para os refugiados. p. xlvii.

${ }^{14}$ JUBILUT, Liliana Lyra. $\mathbf{O}$ direito internacional dos refugiados e sua aplicação no ordenamento jurídico brasileiro. p. 76.
} 
In 1948, after preparatory works conducted by ECOSOC and General Assembly, the International Organization for Refugees was established. Unfortunately, only a few States ratified its constitutive treaty, so the budget was not enough. Nevertheless, its constitutive treaty has expanded the concept of refugee and has also defined the concept of internally displaced persons. "The constitution of the International Organization for Refugees has generated many advances [to international refugee law], especially the individualization of the concept of refugees and the description of the reasons for their persecution."15

The International Organization for Refugees finished its activities in February $28^{\text {th }}, 1952$. The UNHCR was created in January $1^{\text {st }}, 1950$ as a subsidiary body of the United Nations General Assembly, and assumed the functions of the International Organization for Refugees. ${ }^{16}$ On January 1951 the UNHCR started its activities, but its mandate would last for only 3 years, which reflected divergences among UN member-states on the creation of a permanent body. ${ }^{17}$ However, because of the refugee crisis, the mandate of the Office has been renewed every 5 years. ${ }^{18}$ And "[...] in 2003, UNHCR was authorized to continue its work until the refugee problem is solved."19

The UNHCR should ensure international protection for refugees, as well as seek permanent solutions and assist several States. ${ }^{20}$ In addition, it should follow the directive policies set by the General Assembly and the ECOSOC. ${ }^{21}$ It could be considered as refugee any person who was suffering persecution under the terms of the agreements of May $12^{\text {th }}, 1926$ and June $30^{\text {th }}, 1928$; Convention of 1933 and 1938 or the constitutive treaty of International Organization for Refugees. Or, any person who was persecuted by race, religion, nationality or political opinion due to events prior to January $1^{\text {st }}, 1951$ and was outside the country of origin. ${ }^{22}$

In order to ensure such protection, the UNHCR is ought: to promote the drafting and the ratification of international treaties about protection of refugees and to monitor its implementation; to conclude agreements with governments to ensure measures to improve the refugees situation and to reduce the number of applications; to assist the voluntary repatriation or local integration; to facilitate the admission of refugees; to assist in the eventual transfer of refugees asset; to obtain governments information about refugees and theirs conditions in their territories; to maintain permanent contact with

\footnotetext{
${ }^{15}$ ANDRADE, José Fischel de. O Brasil e a organização internacional para os refugiados. p. 10.

16 UNITED NATIONS. General Assembly. Res. 319 (IV). 3 dez 1949. Disponível em: $<$ https://documents-dds-

ny.un.org/doc/RESOLUTION/GEN/NR0/051/38/IMG/NR005138.pdf?OpenElement>. Acesso em 10 jul 2017.

17 UNITED NATIONS. Un introduction to international protection: protecting persons of concern to UNHCR. Geneva: 2005. p. 06.

${ }^{18}$ JUBILUT, Liliana Lyra. 0 direito internacional dos refugiados e sua aplicação no ordenamento jurídico brasileiro. p. 79.

19 UNITED NATIONS. Un introduction to international protection: protecting persons of concern to UNHCR. p. 07.

${ }^{20}$ ORGANIZAÇÃO DAS NAÇÕES UNIDAS. Convenção relativa ao estatuto dos refugiados. 28 jul $1951 . \quad$ Disponível em: $<$ http://www.acnur.org/t3/fileadmin/Documentos/portugues/BDL/Convencao relativa ao Estatuto dos Refugiados.pdf>. Acesso em: 01 jun 2017. Art. 1.

${ }^{21}$ ORGANIZAÇÃO DAS NAÇÕES UNIDAS. Convenção relativa ao estatuto dos refugiados. Art. 3. 22 ORGANIZAÇÃO DAS NAÇÕES UNIDAS. Convenção relativa ao estatuto dos refugiados. Art. 6.
} 
governments and other organizations that also deal with refugees. ${ }^{23}$ Thus, "the international protection of refugees begins with securing their admission to a country of asylum, the grant of asylum and respect for their fundamental human rights, including the right not to be forcibly returned to a country where their safety or survival are threatened [...]."24

Since 1951, UHNCR's functions has been expanded by General Assembly and ECOSOC, to secure the delivery of humanitarian assistance and protection activities to persons other than refugees, such as internally displaced persons and stateless persons. ${ }^{25}$ The UNCHR is the only international agency with specific mandate to protect refugees at global level as well as to protect asylum-seekers, stateless persons and, with restrictions, internally displaced persons.

In addition to the establishment of the UNHCR, many States ratified the Refugee Statute, which is the basis of International Refugee Law and defines who can apply for asylum and the basic treatment and rights to these persons. However, the Convention reflected the political situation of that time, the moment after the World War II. Therefore, its scope was limited to the persons who had become refugees because of facts prior to 1951, that is, Europeans. "It soon became clear, however, that refugee crises were continuing and were not confined to a single continent." ${ }^{26}$ In the next years, the new office had to assist other continents such as Chinese refugees in Hong Kong and Algerians who fled to Morocco and Tunisia. The process of decolonization in Africa made the situation worse, because there was a continuous flow of people fleeing their countries and going to others in conflict. Thus, the international community adopted the 1967 Protocol $^{27}$, which removed the "temporal limit" and the "geographical limit", that is, any person may apply for asylum, not only Europeans and not only because of events prior to $1951 .^{28}$

The 1951 Convention and the 1967 Protocol foresaw that any person who is suffering persecution for reasons of race, religion, nationality, membership of a particular social group or political opinion, and is outside the country of his nationality may apply for asylum. So, besides the persecution, it is also necessary that people flee from their origin country.

Therefore, the Convention and the Protocol do not assist many forced migrants, as persons who cannot cross state borders. Besides, any other reason of persecution will be not considered. As a result, two important regional treaties were adopted. The decolonization process in Africa caused

${ }^{23}$ ORGANIZAÇÃO DAS NAÇÕES UNIDAS. Convenção relativa ao estatuto dos refugiados. Art. 08.

UNITED NATIONS. General Assembly. Res. 428 (V). 14 dez 1950. Disponível em: $<$ https://documents-dds-

ny.un.org/doc/RESOLUTION/GEN/NR0/060/26/IMG/NR006026.pdf?OpenElement>. Acesso em: 10 jul 2017.

${ }^{24}$ UNITED NATIONS. Un introduction to international protection: protecting persons of concern to UNHCR. p. 07.

${ }^{25}$ UNITED NATIONS. Un introduction to international protection: protecting persons of concern to UNHCR. p. 08.

${ }^{26}$ UNITED NATIONS. Un introduction to international protection: protecting persons of concern to UNHCR. p. 09.

27 ORGANIZAÇÃO DAS NAÇÕES UNIDAS. Protocolo de 1967 relativo ao estatuto dos refugiados. $\quad 31 \quad$ jan $1967 . \quad$ Disponível $\quad$ em: $<$ http://www.acnur.org/fileadmin/scripts/doc.php?file=fileadmin/Documentos/portugues/BD Legal/Instr umentos Internacionais/Protocolo de 1967>. Acesso em 01 jun 2017.

${ }^{28}$ UNITED NATIONS. Un introduction to international protection: protecting persons of concern to UNHCR. p. 10. 
many violent conflicts and the Organization of African Union (OAU) discussed the necessity to expand the reasons to apply for asylum. ${ }^{29}$ Then, in 1969 it was created the OAU Convention Governing the Specific Aspects of Refugees Problems in Africa ${ }^{30}$, which defines the following:

1. For the purposes of this Convention, the term "refugee" shall mean every person who, owing to well-founded fear of being persecuted for reasons of race, religion, nationality, membership of a particular social group or political opinion, is outside the country of his nationality and is unable or, owing to such fear, is unwilling to avail himself of the protection of that country, or who, not having a nationality and being outside the country of his former habitual residence as a result of such events, is unable or, owing to such fear, is unwilling to return to it.

2. The term "refugee" shall also apply to every person who, owing to external aggression, occupation, foreign domination or events seriously disturbing public order in either part or the whole of his country of origin or nationality, is compelled to leave his place of habitual residence in order to seek refuge in another place outside his country of origin or nationality.

In 1984, this same issue was discussed in Latin America due to the increase of migratory flows caused by dictatorial regimes in the region. It was held in Colombia the International Coloquium which resulted in the creation of the Cartagena Declaration on Refugees. ${ }^{31}$ It was not an international treaty such as the African Union Convention, but an international document considered as soft law, that is, it is not legally binding as a treaty (hard law), but can be used as a "model law" for countries to adapt their domestic law. The third conclusion of the Declaration ${ }^{32}$ foresees an extension of the term refugee:

To reiterate that, in view of the experience gained from the massive flows of refugees in the Central American area, it is necessary to consider enlarging the concept of a refugee, bearing in mind, as far as appropriate and in the light of the situation prevailing in the region, the precedent of the OAU Convention (article 1, paragraph 2) and the doctrine employed in the reports of the Inter-American Commission on Human Rights. Hence the definition or concept of a refugee to be recommended for use in the region is one which, in addition to containing the elements of the 1951 Convention and the 1967 Protocol, includes among refugees persons who have fled their country because their lives, safety or freedom have been threatened by generalized violence, foreign aggression, internal conflicts, massive violation of human rights or other circumstances which have seriously disturbed public order.

\footnotetext{
29 JUBILUT, Liliana Lyra; MADUREIRA, André, de Lima. Dossiê: migrações forçadas - os desafios de proteção aos refugiados e migrantes forçados no marco de Cartagena+30. Revista Interdisciplinar de Mobilidade Humana. Brasília, v. XXII, n. 43, p. 11-33, jul-dez 2014. p. 15.

30 ORGANIZATION OF AFRICAN UNION. OAU convention governing the specific aspects of refugees problems in Africa. 10 sep 1969. Disponível em: http://www.unhcr.org/aboutus/background/45dc1a682/oau-convention-governing-specific-aspects-refugee-problems-africaadopted.html. Acesso em: 01 jul 2017.

31 JUBILUT, Liliana Lyra; MADUREIRA, André, de Lima. Dossiê: migrações forçadas - os desafios de proteção aos refugiados e migrantes forçados no marco de Cartagena+30. p. 19.

32 DECLARAÇÃO de Cartagena. 22 nov 1984. Disponível em: $<$ http://www.acnur.org/fileadmin/scripts/doc.php?file=fileadmin/Documentos/portugues/BD Legal/Instr umentos Internacionais/Declaracao de Cartagena>. Acesso em 01 jul 2017.
} 
Despite being restricted to Africa and Latin America, these documents expand the possibilities to apply for asylum, including serious violations of human rights, foreign aggression and generalized violence, as well as other circumstances that affect public order.

Even so, the international refugee concept is that one provided by the Convention and the Protocol. It is a restricted concept because there is "[...] an interest of the international community in establishing political and legal categories that constitute barriers to unwanted migration [...]". ${ }^{33}$ So, the international community has shown a great interest about IDPs, once they may become refugee and, therefore, apply for asylum in countries that do not want to receive refugees. ${ }^{34}$ Thus, "internally displaced persons" are people who suffer persecution or violence, but are unable to leave their country of origin and only recently have come to attention of the international community.

\section{INTERNALLY DISPLACED PERSONS}

Until the late 1980s the international community was worried about migrants who crossed the borders of their own country. The expression "internally displaced person" was used only when organizations recognized them as a potential refugee. Nevertheless, internal displacement is a problem as old as migration between countries, but this subject has just obtained notoriety from the 1990s. Eduardo Oliveira ${ }^{35}$ states that:

The delay of its rise to the top of the great humanitarian problem can be explained, in part, by the inexistence, during the Cold War, of an international political environment that debated themes related to state sovereignty and that could be used as justification for external interference.

In addition, since the 1990s, the subject of human rights has obtained great relevance in national and international legal systems. Because of the end of the Cold War, many "local conflicts" broke out in several countries, including the worsening of conflicts in Africa due to the decolonization process initiated in the decade of 1960 . It is, therefore, clear that the issue of conflicts and human rights has been at the top of the international agenda from then on. Thus, internal displacement starts to come to attention of the international community.

Although there was no definition before the 1990s, it is important to mention that there were few times that IDPs were mentioned. According to Maria Beatriz Nogueira, ${ }^{36}$ it first happened in 1972 , by the end of the first Sudanese civil war in which the General Assembly and the ECOSOC determined that UNHCR should coordinate repatriation for Sudanese refugees and displaced

\footnotetext{
${ }^{33}$ POSADA, Paola. Refugiados y desplazados forzados. Categorías de la migración forzadas creadas como medidas de contención a las migraciones no deseadas. Estudios Políticos. n. 35, p. 131-152, jul-dez 2009. p. 138. Tradução do autor.

${ }_{34}$ POSADA, Paola. Refugiados y desplazados forzados. Categorías de la migración forzadas creadas como medidas de contención a las migraciones no deseadas. p. 138.

${ }^{35}$ OLIVEIRA, Eduardo Cançado. A proteção jurídica internacional dos deslocados internos. p. 74.

${ }^{36}$ NOGUEIRA, Maria Beatriz Bonna. A proteção dos deslocados internos na sociedade internacional: evolução conceitual e normativa. Revista da Faculdade de Direito da UFRGS. volume especial, p. 67-91, 2014. p. 72.
} 
persons. ${ }^{37}$ In addition to this case, there are also the following: Indochina ${ }^{38}$; Ethiopia ${ }^{39}$; Chad $^{40}$ and Central America ${ }^{41}$.

Two Conferences were held in the end of 1980s that highlighted the problem concerning IDPs. In 1989, the International Conference on Plight of Refugee, Returnees and Displaced Persons took place in Southern Africa ${ }^{42}$ and the International Conference on Central America Refugees took place at Guatemala City. ${ }^{43}$ In fact, there was no international treaty in these meetings, but UN SecretaryGeneral Javier Pérez de Cuellar, in response to these Conferences, published the first UN Report on Internally Displaced Persons. However, the definition has focused on the difference between these people and refugees, emphasizing that States of origin have primary responsibility to protect their displaced persons. ${ }^{44}$ In 1990, a new report was prepared, but also without a definition. In any case, the issue was getting more attention and the UN Commission on Human Rights drafted its first resolution in 1991. It did not define the term "internally displaced", it emphasized the need for its protection and requested a report from the UN Secretary-General. ${ }^{45}$

According to Maria Beatriz Nogueira, the Secretary-General Boutros Boutros-Ghali drafted the report requested by the Commission and "[...] the first working definition of internally displaced persons". ${ }^{46}$ There are two key elements in this definition: (1) people forced to flee their homes and (2) who remain within the borders of their own country.

For the purposes of this report, the term "internally displaced persons" will be used to refer to persons who have been forced to flee their homes suddenly or unexpectedly in larger numbers; as a result of armed conflict, internal

${ }^{37}$ UNITED NATIONS. Economic and Social Council. Res 1655 (LII). 01 jun 1972. Disponível em:< http://www.refworld.org/docid/3ae69eeb4.html>. Acesso em: 10 jul 2017.

UNITED NATIONS. General Assembly. Res. 2958 (XXVII). 12 dez 1972. Disponível em: $<$ https://documents-dds-

ny.un.org/doc/RESOLUTION/GEN/NR0/269/88/IMG/NR026988.pdf?OpenElement>. Acesso em 11 jul 2017.

38 UNITED NATIONS General Assembly. Res. 3455 (XXX). 09 dez 1975. Disponível em: $<$ https://documents-dds-

ny.un.org/doc/RESOLUTION/GEN/NR0/001/68/IMG/NR000168.pdf?OpenElement>. Acesso em: 11 jul 2017.

39 UNITED NATIONS General Assembly. A/RES/37/175. 17 dez 1982. Disponível em: <http://www.un.org/documents/ga/res/37/a37r175.htm>. Acesso em: 11 jul 2017.

40 UNITED NATIONS. General Assembly. A/RES/39/140. $13 \mathrm{dez}$ 1985. Disponível em: <http://www.un.org/documents/ga/res/40/a40r136.htm>. Acesso em: 11 jul 1985.

41 UNITED NATIONS. General Assembly. A/RES/42/110. 07 dez 1987. Disponível em: $<$ http://www.un.org/documents/ga/res/42/a42r110.htm>. Acesso em: 11 jul 2017.

42 ORGANIZATION OF AFRICAN UNION. International conference on the plight of refugees, returnees and displaced persons in Southern Africa. CM/Res/1181 (XLIX). 25 fev 1989. Disponível em: <http://www.peaceau.org/uploads/cm-res-1181-xlix-e.pdf>. Acesso em: 11 jul 2017. 43 ORGANIZATION OF AMERICAN STATES. General Assembly. AG/RES. 1021(XIX-0/89). 18 nov 1989. Disponível em: <https://www.oas.org/dil/AG-RES 1021 XIX-O-89 eng.pdf>. Acesso $11 \mathrm{jul}$ 2017.

${ }^{44}$ NOGUEIRA, Maria Beatriz Bonna. A proteção dos deslocados internos na sociedade internacional: evolução conceitual e normativa. p. 74.

45 UNITED NATIONS. Comission on Human Rights. E/CN.4/RES/1991/25. 5 mar 1991. Disponível em: <http://www.refworld.org/cgi-bin/texis/vtx/rwmain?page=printdoc\&docid=3b00f0b1c $>$. Acesso em 11 jul 2017.

${ }^{46}$ NOGUEIRA, Maria Beatriz Bonna. A proteção dos deslocados internos na sociedade internacional: evolução conceitual e normativa. p. 78. 
strife, systematic violations of human rights or natural or man-made disasters; and who are within the territory of their own country. ${ }^{47}$

In the next year, the Commission requested the Secretary-General to designate a representative to deal specifically with issues related to displaced persons. ${ }^{48}$ In response to that request, a Special Representative of the Secretary-General of Internally Displaced Persons was assigned for the following functions: to develop international, regional and national laws; to coordinate missions in the States and to research related issues. ${ }^{49}$ And one of the Special Representative's findings was the absence of an international legal document regulating the needs of these people, as well as the absence of UN bodies that could act in emergency situations. Regarding to these agencies, it was established that a mechanism for mobilizing activities would be created among the various agencies that provide humanitarian aid. In regard to a legal document, it was proposed the "Guiding Principles on Internally Displacement", which was unanimously approved by the Commission on Human Rights in $1998 .^{50}$ These Principles $^{51}$ define internally displaced persons as follows:

[...] persons or group of persons who have been forced or obliged to flee or to leave their homes or places of habitual residence, in particular as a result of or in order to avoid the effects of armed conflict, situations of generalized violations of human rights or natural or human-made disasters, and who have not crossed an internationally recognized State border.

Therefore, the main elements of the concept of IDPs are: forced migration which does not go beyond the borders of the State of origin. It should also be noted that, unlike the provisions of the Refugee Statute, there is no provision about persecution based on nationality, race, ethnic origin, religion or political opinion in the Guiding Principles. The reasons for the migration set forth in this document are wider than those foreseen by the Convention. The document does not intend to provide legal status to the IDPs, so it does not determine the reasons to flee.

The flexible and wide definition of displaced people set forth within the Principles has generated several criticisms, especially for including natural or human-made disaster as a reason to flee. ${ }^{52}$ In any case, this is currently the main international document specifically concerning to IDPs, without excluding other international human rights treaties.

It should be noted that there are two regional treaties which emerged from the Guiding Principles: the Protocol on the Protection and Assistance to Internally Displaced Persons (2006) and

\footnotetext{
47 UNITED NATIONS. Comission on Human Rights. E/CN.4/RES/1992/23. 14 feb 1992. Disponível em: $\quad<$ http://repository.un.org/bitstream/handle/11176/188685/E CN.4 1992 23EN.pdf?sequence=3\&isAllowed $=y \geq$. Acesso em: 11 jul 2017.

48 UNITED NATIONS. Comission on Human Rights. E/CN.4/RES/1992/73. 05 mar 1992. Disponível em: <http://www.refworld.org/cgi-bin/texis/vtx/rwmain?page=printdoc\&docid=3b00f0e71c $>$. Acesso em: 11 jul 2017.

49 UNITED NATIONS. Un introduction to international protection: protecting persons of concern to UNHCR. p. 12.

${ }^{50}$ OLIVEIRA, Eduardo Cançado. A proteção jurídica internacional dos deslocados internos. p. 75.

51 UNITED NATIONS. Comission on human rights. Guiding principles on internal displacement . 11 feb 1998. Disponível em: <http://www.un-documents.net/gpid.htm>. Acesso em 09 jul 2017.

52 OLIVEIRA, Eduardo Cançado. A proteção jurídica internacional dos deslocados internos. p. 75.
} 
the Kampala Convention (2009). According to the Protocol ${ }^{53}$ it can be considered as internally displaced person:

[...] persons or groups of persons who have been forced or obliged to flee or to leave their homes or places of habitual residence, in particular as a result of or in order to avoid the effects of armed conflict, situations of generalized violence, violations of human rights or natural or human-made disasters, and who have not crossed an internationally recognized State border;

Internally Displaced Persons: also means persons or groups of persons who have been forced or obliged to flee or to leave their homes or places of habitual residence, in particular as a result of or in order to avoid the effects of large scale development projects, and who have not crossed an internationally recognized State border

The Kampala Convention offers a similar definition ${ }^{54}$ :

\begin{abstract}
'Internally Displaced Persons' means persons or groups of persons who have been forced or obliged to flee or to leave their homes or places of habitual residence, in particular as a result of or in order to avoid the effects of armed conflict, situations of generalized violence, violations of human rights or natural or human-made disasters, and who have not crossed an internationally recognized State border;

'Internal displacement' means the involuntary or forced movement, evacuation or relocation of persons or groups of persons within internationally recognized state borders.
\end{abstract}

The abovementioned definitions are very similar to the one foreseen in the Guiding Principles.

It should also be noted that the situation of IDPs is very different from that of refugees, since displaced persons remain in their own country. Although the refugee situation is very serious and they are not adequately protected, these people are under protection of important treaties unlike the internally displaced persons, who can be persecuted by their own government or even abandoned. ${ }^{55}$ So, it is important to analyze how international law try to protect the IDPs.

\title{
4. THE PROTECTION OF INTERNALLY DISPLACED PERSONS BY INTERNATIONAL LAW
}

As mentioned above, there are a few documents to regulate the issue of IDPs. Such persons are under protection and responsibility of their own State, since they are still in their territory. So, it is difficult to say that there is an international protection for them. But, nowadays this issue is coming to

\footnotetext{
${ }^{53}$ ORGANIZATION OF AFRICAN UNION. Protocol on the protection and assistance to internally displaced persons. 30 nov 2006. Disponível em: <http://www.refworld.org/pdfid/52384fe44.pdf>. Acesso em: 01 jul 2007. Art.1, n. 4-5.

${ }^{54}$ ORGANIZATION OF AFRICAN UNION. African Union convention for the protection and assistance of internally displaced persons in Africa. 22 out 2009. Disponível em: $<$ http://www.unhcr.org/about-us/background/4ae9bede9/african-union-convention-protectionassistance-internally-displaced-persons.html>. Acesso em 11 jul 2017. Art. 1, k-l.

${ }^{55}$ OLIVEIRA, Eduardo Cançado. A proteção jurídica internacional dos deslocados internos. p. 75.
} 
the attention of international community and is being recognized as a humanitarian problem, mainly in connection to the weaken of the principle of non-intervention.

In 1994, it took place the first meeting to revise the Cartagena Declaration which drafted the Declaration on Refugees and Displaced Persons. In fact, this document did not create any rules about displaced people, but emphasized the need to develop basic protection standard. ${ }^{56}$

So, the Guiding Principles of 1998 are the most important document about internally displaced persons. In addition, there are the said African treaties, the Protocol on the Protection and Assistance to Internally Displaced Persons (2006) and the Kampala Convention (2009), but they are restricted to the African continent. In any case, as "hard law" there are only these treaties abovementioned. And, in international level, there are only the Principles that are considered "soft law", that is, it is not legally binding as a treaty and, therefore, it is not directly enforceable. However, although it is not a treaty, the Principles set forth therein reflect the rights foreseen in others international treaties and customary law. Then, it is important to verify these Principles.

First, the document emphasizes, in principle \#1, that the displaced people have the same rights as other people in their country. They shall not be discriminated, and they have the same rights and freedoms foreseen in other international treaties, such as:

a) the right to life (principle \#10): that is, they must be protected against genocide, murder, arbitrary executions, enforced disappearances, starvation as a form of combat, the use of antipersonnel landmines and any other form of violence. This principle was based on rules already existent within the Universal Declaration of Human Rights ${ }^{57}$ (art. 3) and on the following treaties: International Covenant on Civil and Political Rights ${ }^{58}$ (art. 6); Convention Against Torture and Other Cruel, Inhuman or Degrading Treatment or Punishment ${ }^{59}$; Convention on the Prevention and Punishment of the Crime of Genocide ${ }^{60}$; The Rome Statute of the International Criminal Court ${ }^{61}$ (arts. 5, 6, 7 and 8); Convention on the Rights of the Child ${ }^{62}$ (art. 6); Protocol I Additional to the Geneva Conventions of 12 august 1949 relating to the protection of victims of international armed conflicts ${ }^{63}$

\footnotetext{
${ }^{56}$ JUBILUT, Liliana Lyra; MADUREIRA, André, de Lima. Dossiê: migrações forçadas - os desafios de proteção aos refugiados e migrantes forçados no marco de Cartagena+30.

57 ORGANIZAÇÃO DAS NAÇÕES UNIDAS. Declaração universal dos direitos humanos. $10 \mathrm{dez}$ 1948. Disponível em: <http://www.onu.org.br/img/2014/09/DUDH.pdf>. Acesso em: 13 jul 2017.

58 UNITED NATIONS. International covenant on civil and political rights. 19 dec 1966. Disponível em: $\quad<$ https://treaties.un.org/doc/publication/unts/volume\%20999/volume-999-i-14668-english.pdf>. Acesso em: 13 jul 2017.

59 UNITED NATIONS. Convention against torture and other cruel, inhuman or degrading treatment or punishment. 10 dec 1984. Disponível em: <http://www.ohchr.org/EN/Professionallnterest/Pages/CAT.aspx>. Acesso em: 13 jul 2017.

60 UNITED NATIONS. Convention against torture and other cruel, inhuman or degrading treatment or punishment. 10 dec 1984. Disponível em: $<$ http://www.ohchr.org/EN/Professionallnterest/Pages/CAT.aspx>. Acesso em: 13 jul 2017.

61 INTERNATIONAL CRIMINAL COURT. Rome statute of the International Criminal Court. 17 jul 1998. Disponível em: <https://www.icc-cpi.int/nr/rdonlyres/ea9aeff7-5752-4f84-be940a655eb30e16/0/rome statute english.pdf>. Acesso em: 12 jul 2017.

62 UNITED NATION. Convention on the rights of the child. 20 nov 1989. Disponível em: $<$ http://www.ohchr.org/EN/Professionallnterest/Pages/CRC.aspx>. Acesso em: 12 jul 2017.

${ }^{63}$ UNITED NATIONS. Protocol additional to the Geneva Conventions of 12 August 1949, and relating to the protection of victims of international armed conflicts (Protocol I). 8 jun 1977. Disponível em: <https://treaties.un.org/doc/publication/unts/volume\%201125/volume-1125-i-17512english.pdf >. Acesso em: 13 jul 2017.
} 
(art. 51); Protocol II Additional to the Geneva Conventions of 12 august 1949 relating to the protection of victims of non-international armed conflicts ${ }^{64}$ (art. 4); Convention on the Prohibition of the Use, Stockpilling, Production and Transfer of Anti-Personnel Mines and on Their Destruction ${ }^{65}$.

b) the right to dignity and physical, mental and moral integrity (principle \#11): they must be protected especially against rape, mutilations, tortures, inhuman or degrading punishment, slavery, forced prostitution, forced labor of children and others inhuman and degrading treatments. This principle was also based on the Universal Declaration of Human Rights (arts. 4 and 5) and on the following treaties: International Covenant on Civil and Political Rights (arts. 7 e 8); International Covenant on Economic, Social and Cultural Rights ${ }^{66}$ (art. 12); the Convention against Torture and other Cruel, Inhuman or Degrading Treatment or Punishment; International Convention on the Elimination of all Forms of Racial Discrimination ${ }^{67}$ (art. V); Convention on the Prevention and Punishment of the Crime of Genocide; The Rome Statute off The International Criminal Court (arts. 5, 6, 7 and 8); Convention on the Rights of the Child (arts. 19, 34 and 37); Protocol I Additional to the Geneva Conventions of 12 august 1949 relating to the protection of victims of international armed conflicts (arts. 11 and 75); Protocol II Additional to the Geneva Conventions of 12 august 1949 relating to the protection of victims of non-international armed conflicts (art. 4).

c) the right to liberty and security of person: they shall not be arbitrarily arrested. (principle \#12). This principle was based on the Universal Declaration of Human Rights (arts. 3 and 9) and on the following treaties: International Covenant on Civil and Political Rights (art. 9) and Convention on the Rights of the Child (art. 37).

d) children shall not be permitted to take part in hostilities and, as well as adults displaced, shall not be recruited to any armed forces or groups (principle \# 13). This principle was based on the following treaties: the Rome Statute of the International Criminal Court (art. 7); Convention on the Rights of the Child (art. 38); Protocol I Additional to the Geneva Conventions of 12 august 1949 relating to the protection of victims of international armed conflicts (art. 77).

e) the right to liberty of movement and freedom to choose their residence (principle \#14), having the right to move to another part of their country or to leave their country (principle \#15). Besides the Universal Declaration of Human Rights (art. 13), these principles were based on the: International Covenant on Civil and Political Rights (art. 12); International Convention on the Elimination of all Forms of Racial Discrimination (art. V).

\footnotetext{
${ }^{64}$ UNITED NATIONS. Protocol Additional to the Geneva Conventions of 12 August 1949, and Relating to the Protection of Victims of Non-International Armed Conflicts (Protocol II). 8 jun 1977. Disponível em: <http://www.refworld.org/docid/3ae6b37f40.html>. Acesso em: 14 jul 2017. 65 UNITED NATIONS. Convention on the prohibition of the use, stockpiling, production and transfer of anti-personnel mines and on their destruction. 18 sep 1997. Disponível em: $<$ http://www.un.org/Depts/mine/UNDocs/ban trty.htm>. Acesso em 14 jul 2017.

${ }_{66}^{6}$ UNITED NATIONS. International covenant on economic, social and cultural rights. $16 \mathrm{dec}$ 1966. Disponível em: <http://www.ohchr.org/EN/Professionallnterest/Pages/CESCR.aspx>. Acesso em: 13 jul 2017.

67 UNITED NATIONS. International convention on the elimination of all forms of racial discrimination. $21 \quad$ dec $1965 . \quad$ Disponível $\quad$ em: $<$ http://www.ohchr.org/EN/Professionallnterest/Pages/CERD.aspx>. Acesso em: 13 jul 2017.
} 
f) the right to an adequate standard of living, which includes essential food and potable water, appropriate clothing, basic housing and essential medical services and sanitation (principle \#18). It was based on the Universal Declaration of Human Rights (art. 25) and on the following treaties: International Covenant on Economic, Social And Cultural Rights (art. 11); International Convention on the Elimination of all Forms of Racial Discrimination (art. V); Convention on the Rights of the Child (art. 24); Protocol I Additional to the Geneva Conventions of 12 august 1949 relating to the protection of victims of international armed conflicts (art. 10); Protocol II Additional to the Geneva Conventions of 12 august 1949 relating to the protection of victims of non-international armed conflicts (art. 17).

g) the right to receive all documents necessary for the exercise of their legal rights (principle \#20). The Universal Declaration of Human Rights (art. 6) was the basis for this principle, as well as the following treaties: International Covenant on Civil and Political Rights (art. 24); International Convention on the Elimination of All Forms of Racial Discrimination (art. V); Convention on the Rights of the Child (art. 7).

h) the right to protection of property and possessions (principle \#21). Besides the Universal Declaration of Human Rights (art .17), the following treaties were also the basis for this principle: International Convention on the Elimination of All Forms of Racial Discrimination (art. V); the Rome Statute of the International Criminal Court (art. 8); Protocol I Additional to the Geneva Conventions of 12 august 1949 relating to the protection of victims of international armed conflicts (art. 52).

i) the right to freedom of thought, religion, conscience, to vote and to participate in governmental and public affairs (principle \#22). It was based on the Universal Declaration of Human Rights (arts. 19, 20 and 21) and on the following treaties: International Covenant on Civil and Political Rights (arts. 18, 19, 25 and 27); International Convention on the Elimination of All Forms of Racial Discrimination (art. V); Convention on the Rights of the Child (arts. 13 and 14); Protocol II Additional to the Geneva Conventions of 12 august 1949 relating to the protection of victims of non-international armed conflicts (art. 4).

j) the right to education (principle \#23). It was based on the Universal Declaration of Human Rights (art. 26) and on the following treaties: International Covenant on Economic, Social and Cultural Rights (art. 13 and 14); International Convention on the Elimination of All Forms of Racial Discrimination (art. V); Convention on the Rights of the Child (art. 28 and 29); Protocol II Additional to the Geneva Conventions of 12 august 1949 relating to the protection of victims of non-international armed conflicts (art. 4).

According to principle \#2, national authorities shall observe all the principles and they have "[...] the primary duty and responsibility to provide protection and humanitarian assistance to internally displaced persons within their jurisdictions". ${ }^{68}$ National authorities may apply these principles without any discrimination, such as race, sex, religion, nationality or other similar criteria. This issue also finds legal protections on the Universal Declaration of Human Rights (art. 2), as well as on many international treaties: the International Covenant on Civil and Political Rights (arts. 2 and 26); the International Covenant on Economic, Social and Cultural Rights (art. 2); the International Convention on the Elimination of All Forms of Racial Discrimination; Convention on the Elimination of All Forms of

${ }^{68}$ UNITED NATIONS. Guiding principles on internal displacement. Principle \#. 3. 
Discrimination Against Women ${ }^{69}$; the Convention on the Rights of the Child (art. 2); the Protocol I Additional on the Geneva Conventions of 12 august 1949 relating to the protection of victims of international armed conflicts (art. 9) and the Protocol II Additional on the Geneva Conventions of 12 august 1949 relating to the protection of victims of non-international armed conflicts (art. 2). In addition to national authorities, all international actors shall respect the obligations provided in the Guiding Principles (principle \#5).

Therefore, although these Principles do not constitute an international treaty, they are applicable because they are foreseen in several treaties. In addition, it should be noted that the Refugee Statute and the 1967 Protocol may also be applied to IDPs by analogy, in cases that these people can be compared to a refugee. The International Committee of the Red Cross states that:

These principles reflect currently International Law and are widely recognized towards an international framework for the protection of these people during all stages of displacement, including return, resettlement and reintegration. ${ }^{70}$

With respect to the African treaties already mentioned, they both embrace the same guidelines of the Principles, but they are more comprehensive and detailed than the Principles, and, as hard law, the rule set forth therein are legally binding and directly enforceable. The African treaties bind the States parties to all human rights and humanitarian law treaties. In addition, as well as the Guiding Principles, these treaties also foresee that the State of origin has the primary responsibility to provide protection to IDPs and national authorities may request international humanitarian assistance. Although these three legal documents provide that national authorities have primary responsibility for IDPs, it should be noted that, sometimes, these authorities are oppressive and, therefore, they are the reason for forced migration.

Regarding humanitarian aid, the Guiding Principles and the African Treaties obliges States to facilitate the free passage of humanitarian assistance. ${ }^{71}$ According to the Principles, humanitarian assistance should not be regarded as an unfriendly act or even as a violation of the principle of nonintervention. In addition, the principle \#5 foresees that all international actors must respect international human rights and international humanitarian law and shall prevent forced displacement.

Finally, it is important to note that there is no specific agency to assist IDPs, so that the UNHCR also play to role to provide vital assistance for these people whenever the reasons for internal displacement are the same reasons to apply for asylum. It is possible, depending on the situation, that other agencies also provide assistance for IDPs, such as World Health Organization and The United Nations Children's Fund (UNICEF), but the UNHCR is the main responsible. As IDPs remain within

69 UNITED NATIONS. Convention on the elimination of all forms of discrimination against women. $18 \quad$ dec $1979 . \quad$ Disponível $<$ http://www.ohchr.org/Documents/Professionallnterest/cedaw.pdf>. Acesso em: 12 jul 2017.

${ }_{70}$ COMITÉ INTERNACIONAL DA CRUZ VERMELHA. Como o DIH protege os refugiados e os deslocados internos? 22 jan 2015. Disponível em: <https://www.icrc.org/pt/document/como-o-dihprotege-os-refugiados-e-os-deslocados-internos >. Acesso em: 12 jul 2017. Tradução do autor.

71 ORGANIZATION OF AFRICAN UNION. African Union convention for the protection and assistance of internally displaced persons in Africa. art. 3.

UNITED NATIONS. Guiding principles on internal displacement. Principle \# 25. 
their own States, international protection should observe the following criteria: a) the UN General Assembly or other UN main organ shall request or authorize any kind of assistance; b) the consent of all authorities concerned; c) unimpeded access to IDPs; d) the national authorities must respect and protect UNHCR personnel and their partners; e) adequate resources. ${ }^{72}$

As explained in section 3, there is a Special Representative to IDPs, who is responsible for identifying the needs of these people, although there is no operational mandate. The Special Representative has several functions, such as: to negotiate free passage to displaced persons, to negotiate protection and humanitarian assistance and to coordinate resources mobilization. The Special Representative may act at the request of the UN Secretary-General, together with the consent of national authorities of the country affected and under the condition of adequate resources, such as security. ${ }^{73}$

Therefore, International Law for protection of IDPs is a developing field, with few documents to regulate this issue and without any agency specifically established to give assistance to IDPs. Indeed, UNHCR renders humanitarian aid, however only when IDP may be compared to a refugee, that is, when the reason for fleeing is the one of those set forth on the Refugee Statute and IDPs are in the same areas where the refugees are under UNHCR administration. Thus, millions of IDPs are still under no protection. As the definition of IDPs is wider than that of refugees, there are much more IDPs than refugees around the world, and UNHCR recognizes it. $^{74}$

\section{CONCLUSION}

This research had the objective to analyze how International Law regulates the protection of IDPs. First, it was studied the history of legal protection of migration, especially of people who seek protection within their own country. In the beginning, it was thought that this phenomenon would not last too long and conventions and international organs were created for a limited period. Over the years, it was concluded that this phenomenon could last for a long time and some situations, such wars and massive violation of human rights, could force people to leave their homes, just like the current international scene. Nevertheless, the focus was on refugees with little attention to IDPs. States were worried about massive influx of people who could enter in their territories.

After the study about the history of legal protection of migration, it was analyzed the definition of internally displaced person. Lately in 1998 it was created an official concept by an international document: the Guiding Principles. Although this is a very important document, the definition of IDP is not established in a treaty, as it is regarding the term refugee. Besides, this concept was established almost half a century after the drafts of the Refugee Statute.

Therefore, it was possible to verify that it was difficult to set forth a definition for IDP and even more difficult to establish a legal framework by International Law. And almost twenty years after the

\footnotetext{
72 UNITED NATIONS. Un introduction to international protection: protecting persons of concern to UNHCR. p. 88.

${ }^{73}$ UNITED NATIONS. Un introduction to international protection: protecting persons of concern to UNHCR. p. 88

${ }^{74}$ UNITED NATIONS. The UN refugee agency. Global trends 2017.
} 
adoption of the Guiding Principles there is still no other international document. In fact, two treaties were adopted in the Africa continent, but they are restricted to a regional level. Nonetheless, the Principles were based on international treaties regarding human rights and humanitarian law. The only difference between the Guiding Principles and the other treaties is that the first document is specific to IDPs. But the rights set forth therein are established on human rights law and international humanitarian law. In any case, the regulation about protection for IDPs is still obscure, and UN and its member-states need to study and analyze this issue. It is necessary to draft at least a specific treaty to rule the IDPs and also to create an organ to administrate this matter, which could be subsidiary of UNHCR. As regard to a specific treaty, it could be based on the Convention, on the 1967 Protocol and on the Guiding Principles.

Nevertheless, there are some aspects to be consider. The definition of IDPs is wider than the one of refugee. While the Convention foresees restricted reasons to flee, the Guiding Principles do not determine specific reasons, but only mention armed conflict, situations of generalized violations of human rights and even natural or human-made disasters. Then, to draft a treaty for IDPs, it should be considered the definition of the Guiding Principles. Rights already recognized should not be excluded, and it is necessary to turn the Principles into a treaty. It is important to find ways to create an effective protection for IDPs, not only under the human rights protection, but searching for the decrease of the migration across state borders. Most of the current refugees were former internally displaced, therefore, finding solutions to the issue of IDPs means to find solutions for refugees and asylumseekers.

\section{REFERÊNCIAS}

ANDRADE, José Fischel de. O Brasil e a organização internacional para os refugiados. Revista Brasileira de Política Internacional. Brasília, v. 48, n. I, p.60-96, jun 2005.

ANDRADE, José Fischel de. A política de proteção a refugiados da Organização das Nações Unidas - sua gênese no período pós-Guerra (1946-1952). Brasília: UnB. 2006. Disponível em: < http://repositorio.unb.br/handle/10482/3726>. Acesso em: 01 jun 2017.

COMITÉ INTERNACIONAL DA CRUZ VERMELHA. Como o DIH protege os refugiados e os deslocados internos? 22 jan 2015. Disponível em: <https://www.icrc.org/pt/document/como-o-dihprotege-os-refugiados-e-os-deslocados-internos >. Acesso em: 12 jul 2017.

DECLARAÇÃO de Cartagena. 22 nov 1984. Disponível em: $<$ http://www.acnur.org/fileadmin/scripts/doc.php?file=fileadmin/Documentos/portugues/BD Legal/Instr umentos Internacionais/Declaracao de Cartagena>. Acesso em 01 jul 2017.

INTERNATIONAL CRIMINAL COURT. Rome statute of the International Criminal Court. 17 jul 1998. Disponível em: <https://www.icc-cpi.int/nr/rdonlyres/ea9aeff7-5752-4f84-be940a655eb30e16/0/rome statute english.pdf>. Acesso em: 12 jul 2017.

INTERNATIONAL ORGANIZATION FOR MIGRATION. Key migration terms. Disponível em: $<$ https://www.iom.int/key-migration-terms >. Acesso em: 11 jul 2017.

JUBILUT, Liliana Lyra. $O$ direito internacional dos refugiados e sua aplicação no ordenamento jurídico brasileiro. São Paulo: Método, 2007. 240 p. 
JUBILUT, Liliana Lyra; MADUREIRA, André, de Lima. Dossiê: migrações forçadas - os desafios de proteção aos refugiados e migrantes forçados no marco de Cartagena+30. Revista Interdisciplinar de Mobilidade Humana. Brasília, v. XXII, n. 43, p. 11-33, jul-dez 2014.

JUBILUT, Liliana Lyra; MENICUCCI, Silvia. A necessidade de proteção internacional no âmbito da migração. Revista Direito GV. São Paulo, v. 6, n. 1, p. 275-294, jan-jun 2010.

NOGUEIRA, Maria Beatriz Bonna. A proteção dos deslocados internos na sociedade internacional: evolução conceitual e normativa. Revista da Faculdade de Direito da UFRGS. volume especial, $p$. 67-91, 2014.

OLIVEIRA, Eduardo Cançado. A proteção jurídica internacional dos deslocados internos. Revista do Instituto Brasileiro de Direitos Humanos. v. 5, n. 5, p. 73-92, 2004.

ORGANIZAÇÃO DAS NAÇÕES UNIDAS. ACNUR: deslocamento forçado atinge recorde global e afeta 65,3 milhões de pessoas. 21 jun 2016. Disponível em: <https://nacoesunidas.org/acnurdeslocamento-forcado-atinge-recorde-global-e-afeta-653-milhoes-de-pessoas $>$. Acesso em: 25 jun 2017.

ORGANIZAÇÃO DAS NAÇÕES UNIDAS. Convenção relativa ao estatuto dos refugiados. 28 jul $1951 . \quad$ Disponível em: $<$ http://www.acnur.org/t3/fileadmin/Documentos/portugues/BDL/Convencao relativa ao Estatuto dos Refugiados.pdf>. Acesso em: 01 jun 2017.

ORGANIZAÇÃO DAS NAÇÕES UNIDAS. Declaração universal dos direitos humanos. $10 \mathrm{dez}$ 1948. Disponível em: <http://www.onu.org.br/img/2014/09/DUDH.pdf>. Acesso em: 13 jul 2017.

ORGANIZAÇÃO DAS NAÇÕES UNIDAS. Protocolo de 1967 relativo ao estatuto dos refugiados. 31 jan $1967 . \quad$ Disponível em: $<$ http://www.acnur.org/fileadmin/scripts/doc.php?file=fileadmin/Documentos/portugues/BD Legal/Instr umentos Internacionais/Protocolo de 1967>. Acesso em 01 jun 2017.

ORGANIZATION OF AFRICAN UNION. African Union convention for the protection and assistance of internally displaced persons in Africa. 22 out 2009. Disponível em: $<$ http://www.unhcr.org/about-us/background/4ae9bede9/african-union-convention-protectionassistance-internally-displaced-persons.html>. Acesso em 11 jul 2017.

ORGANIZATION OF AFRICAN UNION. International conference on the plight of refugees, returnees and displaced persons in Southern Africa. CM/Res/1181 (XLIX). 25 fev 1989. Disponível em: <http://www.peaceau.org/uploads/cm-res-1181-xlix-e.pdf>. Acesso em: 11 jul 2017.

ORGANIZATION OF AFRICAN UNION. OAU convention governing the specific aspects of refugees problems in Africa. 10 sep 1969. Disponível em: http://www.unhcr.org/aboutus/background/45dc1a682/oau-convention-governing-specific-aspects-refugee-problems-africaadopted.html. Acesso em: 01 jul 2017.

ORGANIZATION OF AFRICAN UNION. Protocol on the protection and assistance to internally displaced persons. 30 nov 2006. Disponível em: <http://www.refworld.org/pdfid/52384fe44.pdf>. Acesso em: 01 jul 2007.

ORGANIZATION OF AMERICAN STATES. General Assembly. AG/RES. 1021(XIX-0/89). 18 nov 1989. Disponível em: <https://www.oas.org/dil/AG-RES 1021 XIX-O-89 eng.pdf>. Acesso $11 \mathrm{jul}$ 2017.

POSADA, Paola. Refugiados y desplazados forzados. Categorías de la migración forzadas creadas como medidas de contención a las migraciones no deseadas. Estudios Políticos. n. 35, p. 131-152, jul-dez 2009. 
UNITED NATIONS. Comission on Human Rights. E/CN.4/RES/1991/25. 5 mar 1991. Disponível em: $<$ http://www.refworld.org/cgi-bin/texis/vtx/rwmain?page=printdoc\&docid=3b00f0b1c $>$. Acesso em 11 jul 2017.

UNITED NATIONS. Comission on Human Rights. E/CN.4/RES/1992/23. 14 feb 1992. Disponível em: $<$ http://repository.un.org/bitstream/handle/11176/188685/E CN.4 1992 23-

EN.pdf?sequence $=3 \&$ isAllowed $=y \geq$. Acesso em: 11 jul 2017

UNITED NATIONS. Comission on Human Rights. E/CN.4/RES/1992/73. 05 mar 1992. Disponível em: $<$ http://www.refworld.org/cgi-bin/texis/vtx/rwmain?page=printdoc\&docid=3b00f0e71c $>$. Acesso em: 11 jul 2017.

UNITED NATIONS. Comission on human rights. Guiding principles on internal displacement . 11 feb 1998. Disponível em: <http://www.un-documents.net/gpid.htm>. Acesso em 09 jul 2017.

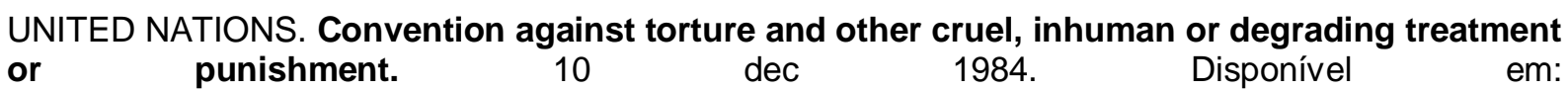
$<$ http://www.ohchr.org/EN/Professionallnterest/Pages/CAT.aspx>. Acesso em: 13 jul 2017.

UNITED NATIONS. Convention on the elimination of all forms of discrimination against women. 18 dec 1979. Disponível em: <http://www.ohchr.org/Documents/Professionallnterest/cedaw.pdf>. Acesso em: 12 jul 2017.

UNITED NATIONS. Convention on the prevention and punishment of the crime of genocide. 9 dec $1948 . \quad$ Disponível em: $<$ http://www.ohchr.org/EN/Professionallnterest/Pages/CrimeOfGenocide.aspx>. Acesso em: 13 jul 2017.

UNITED NATIONS. Convention on the prohibition of the use, stockpiling, production and transfer of anti-personnel mines and on their destruction. 18 sep 1997. Disponível em: $<$ http://www.un.org/Depts/mine/UNDocs/ban trty.htm>. Acesso em 14 jul 2017.

UNITED NATION. Convention on the rights of the child. 20 nov 1989. Disponivel em: <http://www.ohchr.org/EN/Professionallnterest/Pages/CRC.aspx>. Acesso em: 12 jul 2017.

UNITED NATIONS. Economic and Social Council. Res 1655 (LII). 01 jun 1972. Disponível em:< http://www.refworld.org/docid/3ae69eeb4.html>. Acesso em: 10 jul 2017.

UNITED NATIONS General Assembly. A/RES/37/175. 17 dez 1982. Disponível em: <http://www.un.org/documents/ga/res/37/a37r175.htm>. Acesso em: 11 jul 2017.

UNITED NATIONS. General Assembly. A/RES/39/140. 13 dez 1985. Disponível em: <http://www.un.org/documents/ga/res/40/a40r136.htm>. Acesso em: 11 jul 1985.

UNITED NATIONS. General Assembly. A/RES/42/110. 07 dez 1987. Disponível em: <http://www.un.org/documents/ga/res/42/a42r110.htm>. Acesso em: 11 jul 2017.

UNITED NATIONS. General Assembly. Res. 319 (IV). 3 dez 1949. Disponível em: $<$ https://documents-dds-

ny.un.org/doc/RESOLUTION/GEN/NR0/051/38/IMG/NR005138.pdf?OpenElement>. Acesso em 10 jul 2017.

UNITED NATIONS. General Assembly. Res. 428 (V). 14 dez 1950. Disponível em: $<$ https://documents-dds-

ny.un.org/doc/RESOLUTION/GEN/NR0/060/26/IMG/NR006026.pdf?OpenElement>. Acesso em: 10 jul 2017.

UNITED NATIONS. General Assembly. Res. 2958 (XXVII). 12 dez 1972. Disponível em: $<\underline{\text { https://documents-dds- }}$ 
ny.un.org/doc/RESOLUTION/GEN/NR0/269/88/IMG/NR026988.pdf?OpenElement>. Acesso em 11 jul 2017.

UNITED NATIONS General Assembly. Res. 3455 (XXX). 09 dez 1975. Disponível em: $<$ https://documents-dds-

ny.un.org/doc/RESOLUTION/GEN/NR0/001/68/IMG/NR000168.pdf?OpenElement>. Acesso em: 11 jul 2017.

UNITED NATIONS. International covenant on civil and political rights. 19 dec 1966. Disponível em: $\quad$ hhttps://treaties.un.org/doc/publication/unts/volume\%20999/volume-999-i-14668-english.pdf>. Acesso em: 13 jul 2017.

UNITED NATIONS. International covenant on economic, social and cultural rights. 16 dec 1966. Disponível em: <http://www.ohchr.org/EN/Professionallnterest/Pages/CESCR.aspx>. Acesso em: 13 jul 2017.

UNITED NATIONS. International convention on the elimination of all forms of racial $\begin{array}{llllll}\text { discrimination. } & 21 & \text { dec } & 1965 . & \text { Disponível } & \text { em: }\end{array}$ <http://www.ohchr.org/EN/Professionallnterest/Pages/CERD.aspx>. Acesso em: 13 jul 2017.

UNITED NATIONS. Protocol additional to the Geneva Conventions of 12 August 1949, and relating to the protection of victims of international armed conflicts (Protocol I). 8 jun 1977. Disponível em: <https://treaties.un.org/doc/publication/unts/volume\%201125/volume-1125-i-17512english.pdf>. Acesso em: 13 jul 2017.

UNITED NATIONS. Protocol Additional to the Geneva Conventions of 12 August 1949, and Relating to the Protection of Victims of Non-International Armed Conflicts (Protocol II). 8 jun 1977. Disponível em: <http://www.refworld.org/docid/3ae6b37f40.html>. Acesso em: 14 jul 2017.

UNITED NATIONS. The UN refugee agency. Global trends 2017. Disponível em: $<$ http://www.unhcr.org/dach/wp-content/uploads/sites/27/2017/06/2016 Global Trends WEBembargoed.pdf>. Acesso: 06 jul. 2017.

UNITED NATIONS. Un introduction to international protection: protecting persons of concern to UNHCR. Geneva: 2005. 169 p.

\section{COMO CITAR ESSE DOCUMENTO:}

BRIGIDO, Eveline Vieira; ZIBETTI, Fabiola Wust; PILAU SOBRINHO, Liton Lanes. The protection of internaly displaced persons by international migration law. Revista do Direito, Santa Cruz do Sul, v. 1 , n. 54, p. 186-204, jun. 2018. ISSN 1982-9957. Disponível em: <https://online.unisc.br/seer/index.php/direito/article/view/11316>. Acesso em: doi:http://dx.doi.org/10.17058/rdunisc.v1i54.11316. 